"compensated for temperature," were in use when Mr. Fischer was first engaged on the Coast and Geodetic Survey. These gave place to 5-metre contact rods, consisting of a single bar of steel enclosed in a closely fitting wooden case, and covered with padded canvas. For use in the field they were mounted on tripods and placed end to end. In the hands of skilled observers it was possible with this type of bar to attain a degree of accuracy approaching $I$ part in $2,000,000$. In the elaborate apparatus devised by Dr. R. S. Woodward a line bar was supported when in use on a steel trough and covered with crushed ice, the trough being carried by two trucks travelling on a portable track. Micrometer-microscopes were mounted on supports fixed in the ground at carefully measured intervals approximately equal to the length of the bar. The operation of measuring was effected by bringing the bar under the first two microscopes and then setting the cross-wires of the micrometers on the lines of the bar; then without disturbing the reading of the forward micrometer the bar was displaced longitudinally until the line at its rear end was brought under the fo ward microscope, while at the same time an obser er at the forward end set the micrometer on the line at that end, this process being repeated throughout the length of the base line. A kilometre base measured in this manner was estimated to have an accuracy of $x$ part in $3,000,000$.

Eimbeck's duplex base bars were next employed on the survey. These consisted of two concentric brass tubes in the inner of which a brass and a steel measuring bar were mounted. The inner tube could be rotated through $180^{\circ}$ so as to equalise the temperature of the brass and steel components if one side of the apparatus should be more exposed to direct radiation. This method was in its turn superseded by the introduction of invar tapes. All primary bases of the United States Survey are now measured with invar tapes, tested preliminarily at the Bureau of Standards, and by this means base operations, while maintaining the high degree of precision which the work demands, admit of vastly greater rapidity in the field, with a consequent reduction in the expense involved.

\section{PLIOCENE MAN.}

THE discussion originated by the Rev. Osmund Fisher in NATuRE of September 4, 19I3 (vol. xcii., p. 6), has led to the systematic exploration, by a committee of the Dorset Field Club, of the Dewlish "elephant-trench," and the report on the excavations was read at the anniversary meeting on May 4.

This curious trench in the chalk yields bones of the Pliocene Elephas meridionalis, and $\mathrm{Mr}$. Fisher suggested that it was artificial and dug for trapping the elephants. There can no longer be any doubt that the french was of natural origin. The elaborate plans, elevations, and photographs exhibited by Mr. Charles Prideaux, who superintended the excavations, show clearly that a few feet below the surface the supposed trench divides into a chain of pipes or potholes in the chalk connected by a narrow joint. These become very narrow below; but one of them was traced to a depth of $36 \mathrm{ft}$. One or two of the smaller pipes still show traces of the lining of black clay commonly found in pipes caused by solution in the chalk; the larger ones were. filled with chalky sand full of flints, and Tertiary material; many of the flints were beautifully polished. Flakes caused by sudden changes of temperature were also abundant.

Mr. Clement Reid discussed the geological evidence. He thought that it proved the existence of a fissure or joint transverse to the valley of the Devil's Brook. Along this joint a chain of pipes was formed by the

$$
\text { No. } 2376 \text {, voL. 95] }
$$

action of percolating rain-water. Then the pipes nearest to the valley-bottom acted as "swallow-holes," into which the brook sank, the constant swirl of the water laden with calcareous sand giving the flints the wonderful polish now seen. In short, the Devil's Brook, then flowing at a level $90 \mathrm{ft}$. higher, was a "winter bourne," which at Dewlish, for part of the year, at any rate, was swallowed up and disappeared into these pot-holes. Such pot-holes are common in the Carboniferous Limestone, though rare in the Chalk. This chain of pot-holes acted as a natural pitfall, into which the elephants fell, or into which their bones were washed; thus far Osmund Fisher was right in calling it an "elephant-trap," though it probably had a natural origin. Mr. Reid saw no sign of human agency in the trench. The date of the deposit must still remain somewhat uncertain, for all the determinable bones belong: to $E$. meridionalis; and this species, though mainly Pliocene, may have lived on into early Pleistocene times.

Mr. Reid Moir, in another report, described a number of the flints as showing undoubted human workmanship of eolithic type. Mr. Reginald Smith, however, after an examination of the same specimens, thinks that one or two of them may possibly be worked, the others he rejects.

A report by $\mathrm{Mr}$. Dewey pointed out that a sample of calcareous sand from the trench proved under the microscope to consist mainly of minute rhombs of calcite, such as would be precipitated from a saturated solution. This he thought pointed to an arid climate.

\section{SYSTEMATIC ZOOLOGY OF THE INVERTEBRATA.}

$A M O N G$ recent systematic papers on the invertebrates, a noteworthy account of the parasitic worms collected on the British Antarctic (Terra Nova) Expedition, written by Dr. R. T. Leiper and Dr. E. L. Atkinson, has been published by the British Museum ("Terra Nova Zoologv." vol. ii., No. 3). From the summary of results we learn that the Ross Expedition of $184 I^{-4}$ brought back two species of Entozoa; the Scott (Discovery) Expedition of I90I-4 four species; the Bruce (Scotia) Expedition seventeen species; the French (Pourquoi Pas?) Expedition eighteen species; the Terra Nova twenty-eight species. These figures show how greatly zoological knowledge has been increased through our latest national Antarctic enterprise. Three of the worms now recorded from the far south had previously been known only from the Arctic regions. Two of these-a. Filaria and an Echinorrhynchus-have whales as their hosts in both localities, but the third-a monostomid trematode, Ogmogaster plicatum, Creplin-is parasitic in rorquals in the north, and in the Crab-eating and Weddell's Seals in the south; a remarkable divergence in habit.

From home waters there is still much material to be gathered, and C. M. Selbie's important paper on the Decapoda Reptantia of the coasts of Ireland, part i (Fisheries, Ireland, Sci. Invest., I9I4, i.), adds to the fauna of the Britannic marine area the family Eryonidæ, as represented by four species of Polycheles and four of Eryonicus. These were all taken in deep water off the west coast of Ireland, though the specimens of Eryonicus "lead a free-swimming life at a considerable distance from the bottom." The paper is illustrated by fifteen excellently drawn plates.

A very important paper on those interesting copepod fish-parasites, the Lernæopodidæ, has been published by C. B. Wilson in the Proc. U.S. Nat. Museum (vol. xlvii., pp. $\left.56_{5} \rightarrow 29\right)$. Though dealing especially ; with species from North American waters, the author gives a revision of the whole family, thus affording a trust- 
worthy work of reference for students of the group all over the world. "The systematic part of the paper is preceded by a useful introduction to the anatomy and metamorphosis of the parasites, and is illustrated in thirty-two clear plates of diagnostic drawings.

The zoological results of the Abor Expedition (N.E. India) continue to appear in the Records of the Indian Museum. The lately issued part 6 of vol. viii. contains papers on land planarians by Prof. R. H. Whitehouse, terrestrial Isopoda by W. E. Collinge, and Onychophora by Stanley Kemp. The last-named deserve more than passing notice, for the discovery of a Peripatid "at the foot of the eastern Himalaya" is one of the most important faunistic results of recent years, no menber of the class had hitherto been found at all as far north as this. The specimens were found under stones in a comparatively small area at an elevation of $1320 \mathrm{ft}$. From a consideration of the structure of the species, Mr. Kemp considers it allied to the Malayan Eoperipatus, but on account of the total absence of eyes (although the optic ganglia are present), and other distinctive characters, establishes a new genus (Typhloperipatus) for its reception. The unpaired oviduct in the female and the ejaculatory duct (also unpaired) in the male are remarkably long. The eggs are richly. yolked, and embryos at various stages were found in the uterus. From the appearance of the embryos and young it is concluded that reproduction takes place only during the wet season.

G. H. C.

\section{UNIVERSITY AND EDUCATIONAL} INTELLIGENCE.

Cambridge.-Messrs. F. T. Brooks, Emmanuel College, and R. H. Compton, Gonville and Caius College, have been appointed demonstrators of botany, and Mr. T. S. P. Strangeways, St. John's College, has been reappointed demonstrator of physiology. The council recommends to the Senate that the ViceChancellor be authorised to countersign and seal certificates of attendance to Belgian students attending the courses of instruction organised by Belgian professors now lecturing in Cambridge.

The Financial Board has presented a report to the Senate in which the financial position and prospects of the University are reviewed. The income of the University chest for I9I3 and I9I4 was $53,400 l$. and $46,800 l$. respectively, and is estimated at $26,600 l$. for rgr5; the corresponding figures representing the receipts of the common University fund are $22,5 \mathrm{rol}$., $23,800 l$., and ${ }_{5}, 7807$. Details are given in the report of the manner in which the buard proposes to meet the large deficiency disclosed in the estimates by the temporary suspension of vacant teaching and research posts, of salaries to officials now in the national service, and of contributions to pension and building sinking fund accounts. One of the most substantial items of expenditure under the control of the Financial Board is that of grants to the departmental funds of the scientific departments of the University; these amounted to $5580 \mathrm{ol}$. in $19 \times 4$. The accounts of these departments, although controlled by the Board, are not incorporated in those of the University chest or the common University fund, but the board estimates that in igrs the receipts from fees of the scientific departments of the University will fall some $\mathrm{r} 6,00 \mathrm{l}$. to $18,000 l$. below those of I9I4. It is evidently not desired that the University contribution towards the upkeep of the science laboratories in the University should be diminished; it is obvious, however, that even in normal times the chest and the common fund could do little to support natüral science in Cambridge if the annual revenue of the science laboratories were No. 2376 , voL. 95] suddenly diminished by $16,000 l$. to $18,000 l$. The Cambridge Review records the number "of undergraduates in residence this term as 1097 , as against 3 I8I during the Easter term of I9 14.

London.-Lord Rosebery presided at the presentation of graduates on May 5. The annual report of the principal (Sir Henry Miers), his seventh and last report in view of his appointment as Vice-Chancellor of Manchester University, referted to the special work resulting from the war, particularly the training of I 390 officers and educational provision for two hundred refugee students. In his retrospect of his period of office, the principal referred to the report of the Royal Commission, the incorporation of King's College and King's. College for Women in the University, the Universities' Congress, the transfer of Bedford College to Regent's Park, the new buildings at the Imperial College and University College, the development of the professoriate, the increase of internal students from 3580 to $495^{\circ}$, and in the number of external candidates, and many benefactions for teaching and research. He looked forward to the time when the University would have a dignified home bearing its own name, and would be adequately endowed; and expressed his complete faith in its power to fulfil all its duties, both local and imperial. Lord Rosebery, in an eloquent address, hoped that as one result of the war, a new spirit of ce-operation would enable the University to work out its own salvation. He, had never believed that there was anything incompatible between the local and imperial aspects of the work of the University.

The London County Council is prepared to award for the session $1915^{-16}$ a limited number of free places at the Imperial College of Science and Technology, South Kensington, S.W. The free places will be awarded on consideration of the past records of the candidates, the recommendations of their teachers, the course of study which they intend to follow, and generally upon their fitness for advanced study in science as applied to industry. Candidates will not be required to undergo a written examination. It is possible that the free places may be extended to two or more years. Particulars may be obtained from the education officer, L.C.C. Education Offices, Victoria Embankment, W.C., and application forms must be returned not later than Saturday, May 22.

Sherfield.-Dr. J. Sholto C. Douglas, lecturer on pathology in the University of Manchester, has been appointed to the Joseph Hunter chair of pathology, in succession to Prof. Dean.

Four lectures on the progress of public health in Egypt will be delivered at Gresham College, E.C., on May I8-2 I, by Prof. F. M. Sandwith, Gresham professor of physic. The lectures are free to the public, and will begin each evening at six o'clock

WE learn from Science that grants for two new buildings to meet the needs of the University of Ohio and for additional tracts of farm land west of the Olentangy have been voted through the finance committee of the lower branch of the State legislature. These extensions would involve an expenditure of 68 ,oool. A domestic science building to cost $30,000 l$. and a shop building for manual training to cost $24,000 l$. are provided. Ninety acres of land would be purchased west of the Olentangy River at a probable cost of $\mathrm{r}_{4}, 000 \mathrm{l}$.

A Summer School of Mining and Engineering for the South Wales coalfield is to be held in August next at the Technical College, Swansea. The courses of instruction will be seven in number, comprising a surveyor's course (to meet the requirements of the 